\title{
MODERN SCIENTIFIC JOURNAL: OVERLAY, CROWDSOURCING, ALTMETRICS
}

\author{
T.A. POLILOVA* \\ Keldysh Institute of Applied Mathematics of RAS \\ *Corresponding author. E-mail: polilova@ keldysh.ru
}

\section{DOI: 10.20948/mathmontis-2020-48-11}

Summary. The scientific Internet space is actively developing due to the activities of competing participants: publishers of traditional journals with paid access for readers and publishers of Open access journals. Paid journals, using the opportunities of their highly profitable publishing business, offer their users a rich environment of access to the materials of articles. Open access journals are looking for ways to reduce the cost of publishing. The new publication overlay scheme significantly reduces the publisher's expenses. The overlay journal reviews the received article. After the article is accepted for publishing, the article is assigned a DOI and the article's metadata is published on the journal's website along with a link to the full text published in the Open access repository.

The scientific online journal, in contrast to the traditional printed journal, exists in an open information environment, relying on new media and means of communication. The interface with this environment should fully cover all stages of the publishing process - from submission to publication of the article - and further support for changes made by the author based on the results of discussion of the article in the scientific community. One of the key functions of the publishing house is to conduct reviews to ensure the required level of quality of published articles. However, further information technologies come into play, expanding the scope of traditional peer review. In an open environment, any scientist or expert can express their opinion on the merits of an article published on the site within the framework of the problems that they deal with professionally. In the modern world, the reader is not satisfied with the role of a passive consumer of scientific information. Internet technologies and the ideas of Open science have given rise to the ideology of crowdsourcing - all members of the professional scientific community become active participants of the creative process. The opinion of a wide range of specialists should be available to the general reader and participate in the formation of ratings of scientific resources. Articles on the journal's website are accompanied by webometrics and altmetrics indicators that characterize the interest in the article from the scientific Internet community.

\section{INTRODUCTION}

The growth curve of the number of scientific publications in the world over the past two decades has been going up sharply. The number of scientific journals is also growing. Today, it is safe to say that all scientific journals are published on the Internet. If a scientific journal is not available on the Internet, it can be assumed that the journal does not exist [1]. The scientific Internet space of Western countries is actively developing as a result of the activities of competing participants: publishers of traditional journals with paid access for readers and publishers of Open access journals. In the West, in the 60-80-ies of the last century, several 
large publishing houses appeared that publish scientific journals. Publishing scientific journals has become a stable, highly profitable business.

At the same time, the Open access movement began to take shape: in 2002, European countries adopted the Budapest Declaration on free access to research results that were carried out with governmental funding. The concept of Open access implies that any scientist, representative of the educational community or business should have unrestricted access to the world's scientific knowledge and cultural heritage. Open access to scientific information on the Internet is becoming an attractive philosophy for society.

In Russia, the situation with scientific journals is developing according to a special scenario [2]. Editorial and publishing preparation of issues of scientific journals is usually performed by scientific institutes, universities, and other structures with budget funding that have publishing divisions. Editorial boards of journals consist of employees of institutes who perform editorial work, combining it with their main responsibilities. Until the early 90's, russian printed scientific journals were distributed mainly by subscription, while the price of journals was very low - barely covering printing costs. The subscription was used by large libraries, libraries of scientific organizations and universities, as well as scientists.

In the early 2000s, the printings of scientific journals decreased to a minimum - no more than 2-3 hundred copies. Journals began to move smoothly to the Internet, minimizing their expenses. Scientific Online journals with a paid subscription and an embargo period of 2-3 years have appeared. A pleasant event was the order of the Court of Accounts of the Russian Federation in 2018, obliging publishers to make all academic journals freely available.

It is known that since the beginning of the 2000s, Russia has been undergoing permanent reforms affecting the structures of the Academy of Sciences and higher education. The main measure of a researcher's success has become the number of published papers. A significant increase of the publication activity of scientists again attracted attention to scientific journals. New journals began to appear massively. According to the largest russian aggregator of scientific periodicals eLibrary.ru there are 17432 russian scientific journals in it's database, 6213 of them with full texts are in open access. Thus, in Russia, Open access covers about $35 \%$ of scientific journals.

Why have commercial foreign journals ceased to satisfy the scientific community? First of all, for economic reasons: the cost of subscription has become a very significant burden, eating up a huge part of the budget of libraries and scientific institutions. However, major publishers have learned to lobby for their interests, drawing funds from state budgets and scientific foundations. In Russia, lobbyists managed to get paid subscriptions to packages of Western journals for some scientific institutes and universities. The Russian Foundation for basic research conducts annual competitions for access to Western journals.

The model of paid access to scientific journals is implemented by well-known Western publishers with a long history: Springer, Elsevier, Wiley, and Informa. It is claimed that the publication of one peer-reviewed article in the journal Nature costs 40 thousand dollars [3]. Let's compare this amount with the cost of publishing one moderated preprint in arXiv - 10 dollars [3]. Let's ask whether the publisher of the journal Nature is trying to ensure a comfortable existence by obtaining superprofits?

Open access online journals provide their readers with free access to the journal's materials. Who is responsible for the costs associated with editorial and publishing preparation, metadata processing, and so on? One of the business models of Open access journals assumes that expenses are reimbursed by contributions taken from the authors of 
articles. In this case, the author will be asked to pay several thousand us dollars for publishing the article. In the scientific community, there is a growing number of supporters of Fair Open access ideas, calling for a more decisive reduction in the fee for publishing an article [4]. At the same time, there are other examples: the author does not pay any fees for publishing an article (preprint) in the Open archive arXiv. For the initial moderation of articles in arXiv, volunteers employees are involved. The costs (very modest) for maintaining the activities of arXiv are borne by Cornell University (USA).

\section{OPEN ACCESS PUBLICATIONS}

The author has a choice in which journal to publish the article: in the journal of limited (for the reader) access or in the journal of Open access. If an article is submitted to a restricted access journal, the paper will be free of charge. But the readership may be significantly reduced, since not every scientist will be able to pay for access to a closed article. When an open access journal is choosing, the author may have to pay for the costs of publishing the article himself or look for a sponsor.

Note that in addition to the two alternatives (open access and paid access), there are also hybrid models. The journal policy can be flexible. The journal with paid access for the reader opens free access to some publications, if the authors of these articles pay a certain fee. Or an Open access journal with fee for authors may be free of fee for certain categories of authors. In this case, the financial costs are borne by research support funds or publishers themselves.

If the author has decided to publish his article in a journal that is paid for readers, he often retains the opportunity to locate the article as a preprint in an Open repository on the website of his organization, or in a thematic Open archive of preprints, or on his personal page. Often, the author is interested in quick publication. The publishing process of a traditional journal can take several months. During this time, the author may lose priority in their field, and the material of the article may lose relevance. Many restricted access journals allow preprints to appear on the Internet, as Springer published [5]. But the publisher puts forward a condition: if the author's version of the article is published as a preprint, then after accepting the article, the editorial Board suggests that the author indicate in the preprint that the article was accepted and published in the specified journal.

If the article was published as a preprint in an Open repository, it is likely that information about this preprint will reach the mass reader after some time. In ensuring broad access to the article posted on a public website, a greater role plays by search engines such as Google, Yandex. The search service uses its robots (crawlers) to extract metaattributes of articles and place them in its indexes. If a search query for an article appears in search services, it is highly likely that the desired article will appear in the list of responses found. It is more difficult to index an article in Google Scholar. Not every site can be indexed in this service. To do this, the article (or website) must meet certain design requirements [6].

Can an author refuse to re-publish their preprint as a journal article? Unlikely. To obtain the status of a full-fledged scientific work, the article must be published in a peer-reviewed journal. But then there is an ethical problem — the repeated publication of virtually the same text. Some programs for searching for matching texts such as "Antiplagiat" easily detect this kind of duplication and the author will then have to explain that he did not actually violate ethical norms $[7,8]$. And now we should pay attention to a new type of scientific journal - 
an overlay journal that implements an unconventional scheme for organizing interaction between the author and the editorial Board [9].

Overlay journal adheres to three principles: open access, publish for free, and read without restrictions. To implement these principles, we need to reduce the cost of publishing an overlay journal by significantly reducing the cost of publishing articles in the public domain.

The scheme of interaction between the author and the publisher of an overlay journal is as follows. The author publishes his article in an open repository. The article passes moderation, organized by the repository holders. After that, the author sends the article published in the repository to the overlay journal of the corresponding topic. The journal reviews the article. If a positive review is received and the article is accepted for publication, the article is assigned a DOI. The final version of the reviewed article is re-published in the repository as a new version together with a link to the journal. The overlay journal publishes only the article metadata and a link to the final text of the article on the repository site. Thus, an overlay journal is a set of metadata and links to the full texts of peer-reviewed articles.

One example of support for publishing an overlay journal is the Episciences platform [10]. The interface with the publishing platform fully covers all stages of the publishing processfrom submission to publication of the article and further support of the article. Currently, the platform hosts half a dozen open access journals that adhere to the overlay scheme.

The scope of preprint servers is constantly expanding. We can assume that in the near future, overlay journals will occupy a worthy niche and find their authors and readers in various research communities.

\section{THE PEER REVIEW PROCESS}

Scientific journals with high academic standards are very demanding about the quality of published articles. All articles are subject to mandatory review. Such journals openly publish their publishing policies and ethical standards. Journals, in particular, make sure that the author of the article and the reviewer do not have a "conflict of interests". The author should expect an objective review of his article without the influence of group interests or an antagonism of competing scientific schools.

However, the peer review process in journals is often malfunctioning. Not every reviewer can give an objective assessment of the article. Let's remember, for comparison, how the analysis of dissertations goes. Procedures for the defence of the dissertation suggest the presence of two or three opponents. The review of the organization designated by the dissertation Council as the lead organization is also considered. In addition, the dissertation defense takes into account the feedback of scientists who sent their assessments and comments on the dissertation. The decision on the dissertation is made collectively by all members of the Council. For obvious reasons, reviewers of journals will not be able to provide this level of a review.

It should also be mentioned that one of the time-consuming stages of reviewing is often associated with the detection of plagiarism and "self-plagiarism" in the article. There are no questions about plagiarism: it is not only an obvious ethical violation, but also a violation of copyright law. But that can't be said about "self-plagiarism": the author's repeated use of his previously written text does not contradict the current legislation. On the contrary, the practice of some editors to combat such reuse of text often violates the rights of the author. The 
author's inclusion of text fragments from his previously published works in a new article is often dictated by the need to present the context of the research. Authors can use previously published texts in order to ensure self-sufficiency of the article. It is more convenient for readers to have a self-contained text before their eyes, even if it contains fragments of a previously published article by the author, than to switch to another article, losing the context of the current narrative. However, some ethical codes consider such "self-plagiarism" to be an incorrect publishing practice. Journal editors try to avoid possible conflicts and may reject an article if they find intersections with previously published articles. Thus, the journal does not publish an article that is actually a bona fide scientific work [11].

Another example. If the editorial Board charges the author money for publishing the article, the commercial interests of the journal often obscure the objectivity of the review. It is also known that often journals, having achieved high ratings, begin to trade their popularity. Such "predatory" journals promise authors quick access to prestigious Western databases and force authors to pay thousands of dollars for this opportunity. In such cases, we are no longer talking about objective review.

There are cases when publishers launch advertising market projects under the guise of scientific journals. This story happened to the well-known firm Elsevier [12]. Between 2000 and 2005, Elsevier's Australian division published a series of collections of articles intended for family doctors that were actually advertisements for the products of a pharmaceutical company. When this unpleasant story for Elsevier came to light, Michael Hansen, general director of the health sciences division, issued a statement. He admitted that this was an unacceptable practice, and the publisher regrets that such a case took place [13].

The examples can be continued. In 2012, a book was published by British doctor and scientist Ben Goldacr "The whole truth about medicines: the global conspiracy of pharmaceutical companies", dedicated to the description of contractual schemes between representatives of the pharmaceutical industry and doctors. Doctors often fulfilled the role of advertisers by publishing articles about non-existent achievements. There were cases when there were facts of pressure on researchers from pharmaceutical companies to release untested drugs to the market. In 2013 this book was published in the United States, and in 2015 it was translated into Russian [14].

We can mention another reason for doubting the overall objectivity of the review. Scientific knowledge and technologies are developing rapidly. New directions are emerging, including at the intersection of several disciplines. Often in the scientific environment there is a conflict of generations: young researchers often use modern methods that are not mastered by specialists of the older generation. If a reviewer of a classical journal has no experience in a new field and is not familiar with its specifics, he is unlikely to be able to objectively evaluate a pioneer article. The history of science provides many examples when new revolutionary ideas could not break through the wall of misunderstanding of traditionalists for a long time.

Thus, classical review in a traditional journal has no less serious risks than not too deep moderation of the article, which is used, in particular, in arXiv.org. We should not forget that there are other equally reliable ways to verify the quality of the article. As a rule, articles that are interesting and useful for specialists have good traffic indicators and high indicators of alternative metrics. Here we can also talk about high rates of bibliographic citation, but with some clauses. 


\section{THE CITATION USING BIBLIOGRAPHIC LINKS}

Bibliography in the article began to play a special role after the appearance of bibliographic databases that aggregate data from scientific journals, and after the creation of computer methods for processing bibliographic references from the texts of articles. It is now possible to identify automatically links between articles and journals on the base of the analysis of lists of cited literature. Bibliometrics has developed rapidly as a set of methods for evaluating the publication activity of scientists and methods for building journal ratings. The period of interest in the bibliometrics is not over yet. The pillars of the bibliometrics are the leading Western databases Web of Science and Scopus, and many large national electronic repositories. The largest Russian Scientific electronic library, eLibrary, contributes to the bibliometrics movement.

Some countries, when evaluate the effectiveness of national research, rely on citation indicators for scientific articles. In other countries, such as the United Kingdom, the assessment of scientific effectiveness is mainly based on expert assessment. A recent study by the UK Research Excellence Framework (REF) found notable discrepancies between citationbased metrics and peer review results. It should be noted that earlier similar studies showed a higher degree of agreement between metrics and expert assessments, which was the reason for introducing metric indicators. Now there is considerable uncertainty about the feasibility of relying on citation metrics [15].

If you are planning, for example, to publish an article in the leading journal Nature, you will have to prepare the bibliography of 30-40 items. A short bibliographic list may be interpreted by the editorial Board as the author's lack of the necessary outlook in the field of research under consideration. But the point here is not only and not so much in demonstrating immersion in the subject area. The entire industry of evaluating the quality of articles and the prestige of journals is based on the bibliographic lists. The author's h-index is calculated based on the number of citations of the article in other articles. The journal's impact factor is calculated based on the citation count of articles in the journal. And then the ratings of authors and journals are built on the basis of these indicators. But when a certain technology is superimposed on real publishing practice, there are often unnatural relationships between the participants in the process. Special behavior of authors and editors of journals is formed. The authors can agree on a mutual citation. A similar collusion may occur among a group of journals in order to raise the impact factor to each other. Intermediaries immediately appear with offers to increase the h-index for a fee: you can find dozens of offers of this type on the Internet.

Note that citation indicators based on the analysis of bibliographic lists are not accurate and comprehensive. There is also the problem of lost links. This problem occurs when authors deviate from the prescribed formats of bibliographic references, make significant errors in the spelling of authors ' surnames and names, or make inaccuracies in the title of the article or other parameters of the link. Usually, bibliographic databases have tools that can be used to find lost citations and edit inaccurate bibliographic references. The paper [16] describes the experience of correcting bibliographic references pointing to Russian journals indexed in Web of Science. After correcting the links, the impact factor indicators of a group of Russian journals in Web of Science increased by $4-37 \%$. One more convincing example can be given: after clarifying the links to the articles of the journal "Keldysh Institute Preprints" in the eLibrary.ru in 2017, the number of citations of the journal increased three times. 
The disadvantages of indicators based on the analysis of bibliographic references should include their binding to a specific bibliographic database. If your article is referenced from articles and journals that are not related to the subject areas of the bibliographic database, such citations will not be taken into account. As a result, the author has several significantly different indicators of the h-index from different bibliographic databases. The problem of combining citation counters for the same article from different bibliographic databases does not yet have a comprehensive solution. Approaches to solving this problem are presented in [17].

In addition, the h-index and journal impact factor indicators are very inertial, they are formed over a long time and are usually calculated no more than once a year. To calculate a two-year indicator, the database must have issues of the journal for the previous 3 years, and for a five-year indicator you need issues of journals for the previous 5 years.

Citation indicators are formed more dynamically based on the analysis of bibliographic lists of articles in the Google Scholar system. This system uses data from a wide variety of open online sources. The data collection process is automated: programs have been developed that view web pages and extract information from metadata descriptions, as well as directly from article texts. In Google Scholar, the author's h-index is usually higher than similar indicators of such Western bibliographic databases as Web of Science, Scopus, or the Russian electronic library eLibrary.ru.

Another disadvantage of the citation index is that it ignores the context and the reason for citation. In most cases, the citation indicates a high popularity of the article. However, the author can also refer to the article for reasons of disagreement with certain provisions or with the General conclusions of the article. Referring to an article with incorrect content, in the author's opinion, the author further in his article expresses his own alternative opinion. But a traditional bibliographic link does not convey the context of the citation, thus the author of a bad article will increase his citation index and will claim the status of an authoritative scientist.

There is also the problem of forgotten authors who were the first to get significant results. This problem can occur when an author has published their pioneering results in a modest journal without high ratings. The article can be quoted and explained by another author who is published in a more prestigious journal. Further, readers who are interested in the published result will prefer to cite a publication in a prestigious journal, since they thereby increase the authority of their own article by using the authority of the cited journal. Such chains of citations lead to the loss of information about the author who was the first to receive an interesting scientific result. In continuation of this topic, we can give an example of preprints. It is known that after the publication of a preprint, the author usually publishes an article in the journal based on the materials of the preprint. Further, we often see that the number of citations of a preprint is much less than the number of citations of a journal article. This is despite the fact that the preprint is the primary source of the obtained scientific result.

\section{ALTMETRICS AND CROWDSOURCING}

Developing Internet technologies have significantly changed the approaches to assessing the significance of articles and the influence of ideas presented in articles on the development of science. There are tools that allow you to count the number of requests to a scientific article 
and the number of downloads of the article, and show the geography of requests. Most of holders of scientific Internet resources have counters of webometric information on their sites. Web Analytics tools continue to evolve. Attempts are made to identify a set of quantitative indicators that give a clear and unambiguous assessment of the level of motivation of the user to get acquainted with the resource materials [18].

Do not think that the high quality of the article will ensure its success in the web environment. The author must make sure that the article is easy to notice.

One of the most common ways to find an article is to make a request in a universal search service (for example, in Google). If the search was successful, this indicates a good visibility of the article on the Internet. However, if the author of the article actively uses social networks and participates in forums, dedicated to discussing scientific problems, his visibility on the Internet increases further. There is the separate direction [19] related to the assessment of the article's popularity in such systems that are still unconventional for scientists as social networks, forums, and specialized platforms for scientific discussions. This direction is called altimetry. The Altmetrics Manifesto was published in 2010 [20].

The results of scientific research are multidimensional. They can include achievements in a specific scientific direction, in an interdisciplinary methodology, in the development of research technologies. Finally, scientific results can have a social effect, bringing new ideas to broad social groups - from researchers to politicians. The evaluation of such a scientific result should also be multidimensional; it is hardly possible to successfully apply any one metric or one evaluation model [21].

A large amount of the material related to the development of scientific ideas and understanding of the results obtained does not fall into traditional journal articles. Such materials remain in the records of open discussions, on the personal pages of scientists, on the pages of Institute websites, in educational materials for students, in comments to articles, in publications in the media [22]. Using existing services such as Mendeley, CiteULike, or Zotero, scientists can organize their personal library of materials that do not have the format of the scientific article, and thus make these materials available to Internet users [20].

In some cases, a scientist may write a short note that other scientists might later cite. However, such a "nanopublication" traditional journal, most likely, will not be able to publish. As a result, readers will not be able to find a note using search tools focused on finding journal articles. Other search queries are required here. Altmetrics should establish mechanisms accounting for this kind of "nanopublications".

Scientists widely exchange data sets, software codes, experimental techniques, algorithms, etc. ("raw science"). Authors who have received such data do not collect traditional authority ratings - their h-index does not depend on the results associated with obtaining and publishing data sets on websites or in archives. Other indicators are required that take into account this contribution of the scientist. This direction is also included in the area of interest of altmetrics.

One of the characteristics of the article is the review. Until recently, the materials of reviews remained on the shelves of publishers. Currently, the idea of placing reviews together with the article in open access is often implemented, which also fits into the philosophy of altmetrics. In addition, the modern review ceases to be a one-time text accompanying the article. The structure of review materials becomes more complex. The review process develops in a dialogue between the reviewer and the author, and the content of this dialogue is of interest to the readers of the article. There are also versions of the article with regular 
changes made after the discussion. After the article is published, the author can get a new review from interested experts, or conduct peer-review in another overlay journal. Reviewing, generally speaking, is not limited in time. Each review gives the author a reason to continue developing his published material. Thus, the article becomes the "alive publication" [23].

Internet technologies and the ideology of Open science make it possible to implement crowdsourcing-style peer review, when a representative community of experts, not just reviewers appointed by the editorial Board, participates in evaluating the quality of an Internet resource. This approach to peer-reviewing is implemented, for example, in the F1000research project [24], where any of several thousand experts of this project can evaluate the article and its additional materials.

F1000research is an Open science publishing platform for rapid publication of scientific articles in the fields of physical and biological sciences, engineering, medicine, social sciences, and humanities. How is the review process organized on this platform? Original articles are accepted for publication, regardless of the intended level of interest or novelty. All articles are published in open access. Authors are invited to attach detailed descriptions of methods, posters, and slides to the text of the article. The author also has the option to provide a link to the original data underlying the study to ensure reproducibility of the results.

The article submitted to F1000Research first passes a quick initial check for compliance with the general editorial practice and is placed on the site with the status "waiting for expert evaluation". Then an open review is conducted, with the authors and reviewers collaborating to make the article as complete as possible. The names of reviewers and the status they assign to the article after reviewing are published together with the article. In the future, any other expert of the f1000research publishing house also has the right to review the article on its own initiative, further clarifying its status. As soon as an article gets two "Approved" status, or two "Approved with reservations" status and one "Approved" status, it will be indexed in various bibliographic databases (in PubMed, PubMed Central, MEDLINE, etc.). If the article is indexed, all versions along with the review reports are sent for storage.

Do experts have incentives to take on the work of reviewing articles? Yes, the F1000Research project has created such a mechanism. The name of the expert and his reviews are open to the entire community, thus actively and conscientiously working expert increases his rating. In addition, there is a noticeable discount for experts who participate in reviewing articles when paying their personal contribution for future publications [25]. By stimulating the activity of experts and authors, the F1000Research project consolidates the scientific community and allows each scientist to participate in the formation of a collective scientific product. Articles in F1000Research can be updated and supplemented at any time after publication, and each version can be independently quoted with its own DOI. The editorial Board suggests the following format for a link to the article [26]:

Author name(s). Article title [version number; details of peer review status]. F1000Research Year, Volume: Publication number (article doi)

All components of the cited bibliographic reference are clear to the reader. The "Status" attribute will require additional explanation. The status indicates the number of checks that are "approved", "approved with reservations", or "not approved".

In addition, regardless of the article, the review itself becomes the object of citation. The review is published under the CC BY 4.0 license, and each review is assigned a DOI. The platform offers the following format for a link to a review [26]: 
Reviewer name(s). Peer review report for: Article title [version number; details of peer review status]. F1000Research Year, Volume: Publication number (review doi)

\section{CONCLUSION}

In our opinion, the evaluation of a scientific article should be multi-dimensional. Classical peer review has risks no less serious than shallow moderation, followed by crowdsourcing, which is active throughout the life of the article. Crowdsourcing in a scientific publication can be defined in simple words: the community of scientists is a powerful resource, and connecting this resource to the review of scientific articles makes it possible to get a better scientific product. On the site of the article, in addition to the review, the reader would be interested to see altmetrics indicators obtained from information from social networks, thematic blogs and forums for professional communication.

The assessment of the scientific significance of an article has been based only on bibliometric indicators based on the analysis of bibliographic references to it for several decades. In our opinion, obtaining indicators based on the analysis of bibliographic references in quoting articles is too long in time, sensitive to errors in the recording of references and unrepresentative, since it is usually limited to one specific bibliographic base.

A promising direction in scientific publishing practice is the overlay journal, which reviews articles from open archives of preprints. After the article is published, the author can get a new review from interested experts, or conduct a review in another overlay journal. Post-review, generally speaking, is not limited in time. Reviews and feedback from colleagues inspire the author to continue developing his article. Thus, the article becomes the "alive publication".

The struggle imposed on the scientific community for high rates of bibliographic citation and for increasing the number of publications in highly rated journals obscures significantly more important tasks: the development of Open access infrastructure, the creation of communication tools for participants in the publishing process, and the enrichment of the means of presenting scientific materials on open publishing platforms.

\section{REFERENCES}

[1] M. M. Gorbunov-Posadov, T. A. Polilova, "Tools to Support Scientific Online Publishing", Programming and Computer Software, 45 (3), 116-120 (2019). https://link.springer.com/article/10.1134\%2FS0361768819030046

[2] S. Beliaeva, "Tsena otkrytosti: Vo chto oboidetsia perekhod k Open Access?", Poisk. (2019). https://www.poisknews.ru/skript/czena-otkrytosti-vo-chto-obojdetsya-perehod-k-open-access/

[3] J.R. Adler, T.M. Chan, J.B. Blain, B. Thoma, Atkinson, "OpenAccess: Free online, open-access crowdsource-reviewed publishing is the future; traditional peer-reviewed journals are on the way out", Canadian Journal of Emergency Medicine, 21 (1), 11- 14 (2019). https://doi.org/10.1017/cem.2018.481

[4] Fair Open Access Alliance. https://www.fairopenaccess.org/ (Accessed July 22, 2020)

[5] Springer, Self-archiving policy. https://www.springer.com/gp/open-access/publicationpolicies/self-archiving-policy (Accessed July 22, 2020)

[6] Google Scholar, Inclusion Guidelines for Webmasters. https://scholar.google.com/intl/en- 
US/scholar/inclusion.html\#overview (Accessed July 22, 2020)

[7] T.A. Polilova. "Ethical norms and legal framework of scientific publication". Mathematica Montisnigri, XLV, 129-136 (2019) http://www.montis.pmf.ac.me/vol45/11.pdf doi: 10.20948/mathmontis-2019-45-11

[8] T.A. Polilova, "Nauchnaia publikatsiia v Rossii: intellektualnye prava", Preprinty IPM im. M.V. Keldysha. 56, 1-24 (2019). http://keldysh.ru/papers/2019/prep2019_56.pdf doi:10.20948/prepr-2019-56

[9] E. Herman, J. Akeroyd, G. Bequet, D. Nicholas, A. Watkinson. "The changed - and changing - landscape of serials publishing: Review of the literature on emerging models", Learned Publishing. (2020). https://doi.org/10.1002/leap.1288 https://onlinelibrary.wiley.com/doi/full/10.1002/leap.1288

[10] Episciences.org, Overlay Journal Platform. www.episciences.org/?lang=en (Accessed July 22, 2020)

[11] T. Polilova, A. Ermakov, "Dissernet and self-plagiarism", CEUR Workshop Proceedings, 2543, 285-294 (2020). https://www.scopus.com/record/display.uri?eid=2-s2.0$\underline{85078459740 \& \text { origin }=\text { resultslist } \& \text { sort }=\text { plf-f } \& \text { src }=\text { s \&st } 1=\text { Dissernet }+ \text { and+self- }}$ plagiarism\&st $2=\&$ sid $=\mathrm{d} 8727 \mathrm{e} 9 \mathrm{f} 55 \mathrm{ec} 2 \mathrm{~b} 7 \mathrm{fc} 177 \mathrm{de} 73 \mathrm{ce} 64 \mathrm{e} 6 \mathrm{~d} 1 \&$ sot $=\mathrm{b} \& \mathrm{sdt}=\mathrm{b} \& \mathrm{sl}=44 \& \mathrm{~s}=\mathrm{TITL}$ E-ABS-KEY\%28Dissernet+and+self-plagiarism\%29\&relpos $=0 \&$ citeCnt $=0 \&$ searchTerm $=$ (Accessed July 22, 2020)

[12] Wikipedia, Elsevier. https://ru.wikipedia.org/wiki/Elsevier (Accessed July 22, 2020)

[13] Tom Reller. Statement From Michael Hansen, CEO Of Elsevier's Health Sciences Division, Regarding Australia Based Sponsored Journal Practices Between 2000 And 2005. https://www.elsevier.com/about/press-releases/clinical-solutions/statement-from-michaelhansen,-ceo-of-elseviers-health-sciences-division,-regarding-australia-based-sponsoredjournal-practices-between-2000-and-2005 (Accessed July 22, 2020)

[14] "Vsia pravda o lekarstvakh, Google i bestsellerah, Galina Iuzefovich — pro knigi, kotorye vse obieiasniaiut". https://meduza.io/feature/2015/07/04/vsya-pravda-o-lekarstvah-google-ibestsellerah (Accessed July 22, 2020)

[15] V.A. Traag, L. Waltman, "Systematic analysis of agreement between metrics and peer review in the UK REF", Palgrave Communications, 5, Article number: 29 (2019). https://doi.org/10.1057/s41599-019-0233-x

[16] D.E. Chebukov, "Poisk poteriannykh tsitirovanii v Web of Science. Ispravlenie oshibok v spiskakh literatury Web of Science", Nauchnyi servis v seti Internet, 461-467 (2017). http://keldysh.ru/abrau/2017/77.pdf doi:10.20948/abrau-2017-77

[17] YongGao QiangWu LinnaZhu, "Merging the citations received by arXiv-deposited e-prints and their corresponding published journal articles: Problems and perspectives", Information Processing \& Management, 57 (5), (2020). https://doi.org/10.1016/j.ipm.2020.102267

[18] Iu.G. Reviakin, "Web-analitika dlia nauchnykh publikatsii", Preprinty IPM im. M.V. Keldysha, 50, 1-42 (2020). http://keldysh.ru/papers/2020/prep2020 50.pdf doi:10.20948/prepr-2020-50

[19] M.N. Saushkin, D.E. Chebukov, "Altmetriki na saite nauchnogo zhurnala", Nauchnyi servis v seti Internet, 593-599 (2019). http://keldysh.ru/abrau/2019/theses/40.pdf doi:10.20948/abrau-2019-40

[20] J. Priem, D. Taraborelli, P. Groth, C. Neylon, “Altmetrics: A manifesto”, (2010). http://altmetrics.org/manifesto (Accessed July 22, 2020)

[21] M. V. Vakhrushev, "Altmetriki, vebometriki i informetriki kak vzaimodopolniaiushchie napravleniia v sovremennoi bibliometrii", Nauchnye i tekhnicheskie biblioteki, 8, 67-76 (2019). https://ntb.gpntb.ru/jour/article/viewFile/470/453

[22] A. Grossmann, "Publishing in transition - do we still need scientific journals?", ScienceOpen Research, (2015). https://www.scienceopen.com/document_file/e1dd3665-6406-4a32-befc- 
e00d84a72cd1/ScienceOpen/3077_XE696973259861784096.pdf doi: 10.14293/S21991006.1.SOR-SOCSCI.ACKE0Y.v1

[23] M.M. Gorbunov-Posadov, "Zhivaia publikatsiia”, (Moscow: KIAM). https://keldysh.ru/gorbunov/live.htm (Accessed July 22, 2020)

[24] F1000Research. Open for Science. https://f1000research.com/ (Accessed July 22, 2020)

[25] F1000Research. Open for Science: Referee Incentives. http://f1000research.com/refereeincentives (Accessed July 22, 2020)

[26] F1000Research. Open for Science: How it Works. https://f1000research.com/about (Accessed July 22, 2020)

Received June 10, 2020 


\title{
СОВРЕМЕННЫЙ НАУЧНЫЙ ЖУРНАЛ: ОВЕРЛЕЙ, КРАУДСОРСИНГ, АЛЬТМЕТРИКИ
}

\author{
т.А. ПОЛИЛОВА* \\ Институт прикладной математики им. М.В. Келдыша РАН. Москва, Россия \\ *Ответственный автор. E-mail: polilova@keldysh.ru
}

\section{DOI: 10.20948/mathmontis-2020-48-11}

Ключевые слова: научная публикация, рецензирование, краудсорсинг, оверлейный журнал, альтметрики.

Аннотация. Научное интернет-пространство активно развивается в результате деятельности конкурирующих участников: издателей традиционных журналов платного для читателя доступа и издателей журналов Открытого доступа. Платные журналы, используя возможности своего высокодоходного издательского бизнеса, предлагают своим пользователям насыщенную среду доступа к материалам статей. Журналы Открытого доступа изыскивают возможности удешевления затрат на издание. Новая оверлейная схема издания позволяет заметно снизить расходы издателя. Оверлейный журнал выполняет рецензирование поступившей статьи. После принятия статьи к изданию статье присваивается DOI и на сайте журнала размещаются метаданные статьи вместе с ссылкой на полный текст, размещенный в репозитории Открытого доступа.

Онлайновый научный журнал, в отличие от своего прародителя традиционного печатного журнала, существует в открытой информационной среде, опираясь на новые медиа и средства коммуникации. Интерфейс с этой средой должен полностью охватывать все стадии издательского процесса - от представления до опубликования статьи - и далее сопровождение вносимых автором изменений по результатам обсуждения статьи в научном сообществе. Одна из ключевых функций издательства проведение рецензирования для обеспечения требуемого уровня качества публикуемых статей. Однако далее в игру вступают информационные технологии, расширяющие сферу применения традиционного рецензирования. В открытой среде любой ученый или эксперт может высказать свое мнение о достоинствах размещенной на сайте статьи в рамках тех проблем, которыми он занимается профессионально. В современном мире читатель не удовлетворяется ролью пассивного потребителя научной информации. Технологии интернета и идеи Открытой науки породили идеологию краудсорсинга все члены профессионального научного сообщества становятся активными участниками творческого процесса. Мнение широких кругов специалистов должно быть доступно для массового читателя и участвовать в формировании рейтингов научных ресурсов. Статьи на сайте журнала сопровождаются вебометрическими и альтметрическими показателями, которые характеризуют интерес к статье со стороны научного интернет-сообщества. 


\section{1 ВВЕДЕНИЕ}

Кривая роста числа научных публикаций в мире в последние два десятилетия резко идет вверх. Растет и количество научных журналов. Сегодня можно с уверенностью заявить, что все научные журналы размещаются в интернете. Если научный журнал не представлен в интернете, можно считать, что он не существует [1]. Научное интернетпространство западных стран активно развивается в результате деятельности конкурирующих участников: издателей традиционных журналов платного для читателей доступа и издателей журналов Открытого доступа. На Западе еще в 60-80-х годах прошлого столетия появились несколько крупных издательств, занимающихся изданием научных журналов. Выпуск научных журналов превратился в стабильный высокодоходный бизнес.

В то же время стало формироваться движение Открытого доступа: в 2002 году европейские страны приняли Будапештскую декларацию о свободном доступе к результатам исследований, выполненных при государственном финансировании. Концепция Открытого доступа предполагает, что любой ученый, представитель образовательного сообщества или бизнеса должен иметь беспрепятственный доступ к мировому научному знанию и культурному наследию. Открытый доступ к научной информации в интернете становится привлекательной для общества философией.

В России ситуация с научными журналами развивается по особому сценарию [2]. Редакционно-издательскую подготовку выпусков научных журналов выполняют, как правило, научные институты, вузы, иные структуры с бюджетным финансированием, имеющие издательские подразделения. Редколлегии журналов состоят из сотрудников институтов, выполняющих редакционную работу, совмещая ее со своими основными обязанностями. До начала $90-\mathrm{x}$ годов российские печатные научные журналы распространялись преимущественно по подписке, при этом цена журналов была весьма низкой - едва покрывала полиграфические расходы. Подпиской пользовались крупные библиотеки, библиотеки научных организаций и вузов, а также ученые.

В начале 2000-х годов тиражи научных журналов в бумажном исполнении снизились до минимума - не превышали 2-3 сотен экземпляров. Журналы стали плавно перемещаться в интернет, минимизируя свои затраты. Появились онлайновые научные журналы с платной подпиской и периодом эмбарго в 2-3 года. Приятным событием стало распоряжение Счетной палаты РФ в 2018 г., обязывающее издателей выкладывать в свободный доступ все академические журналы.

Известно, что с начала 2000-х годов в России шли перманентные реформы, затрагивающие структуры Академии наук и высшей школы. Главным мерилом успешной работы научного сотрудника стало количество опубликованных им работ. Значительное повышение публикационной активности ученых вновь привлекло внимание к научным журналам. Стали массово появляться новые журналы. По данным крупнейшего российского агрегатора научной периодики eLibrary.ru на текущий момент в его базе насчитывается 17432 российских научных журналов, из них 6213 - с полными текстами в открытом доступе. Таким образом, в России Открытый доступ охватывает около 35\% научных журналов.

Почему коммерческие, платные для читателя, западные журналы перестали удовлетворять научное сообщество? Прежде всего, по экономическим причинам: стоимость подписки стала весьма ощутимым бременем, съедая огромную часть 
бюджета библиотек и научных учреждений. Однако крупные издатели научились лоббировать свои интересы, вытягивая средства из бюджетов государств и научных фондов. В России лоббистам удалось добиться платной подписки на пакеты западных журналов для части научных институтов и вузов. Ежегодные конкурсы на получение доступа к западным журналам проводит Российский фонд фундаментальных исследований.

Модель платного доступа к научным журналам реализуют известные западные издательства с многолетней историей: Springer, Elsevier, Wiley, Informa. Утверждается, что публикация одной рецензируемой статьи в журнале Nature обходится в 40 тысяч долларов [3]. Сравним эту сумму с себестоимостью публикации одного модерируемого препринта в arXiv - 10 долларов [3]. Зададим вопрос, не пытается ли издатель журнала Nature обеспечить себе безбедное существование за счет получения сверхприбыли?

Онлайновые журналы Открытого доступа предоставляют своим читателям бесплатный доступ к материалам журнала. Кто же несет расходы, связанные с редакционно-издательской подготовкой, обработкой метаданных и пр.? Одна из бизнес-моделей журналов Открытого доступа предполагает, что расходы возмещаются за счет взносов, берущихся с авторов статей. В этом случае за публикацию статьи автору будет предложено заплатить несколько тысяч долларов США. В научном сообществе растет число сторонников идей Справедливого Открытого доступа, призывающих более решительно снизить плату за публикацию статьи [4]. В то же время есть и другие примеры: за размещение статьи (препринта) в Открытом архиве препринтов arXiv автор не платит каких-либо взносов. К первичной модерации статей в arXiv привлекаются сотрудники-энтузиасты. Расходы (весьма скромные) на поддержание деятельности arXiv несет Корнеллский университет (США).

\section{2 ПУБЛИКАЦИЯ В ОТКРЫТОМ ДОСТУПЕ}

Перед автором стоит выбор, в каком журнале опубликовать статью: в журнале ограниченного (для читателя) доступа или в журнале Открытого доступа. В случае передачи статьи в журнал ограниченного доступа оплату с автора не потребуют. Но читательская аудитория может заметно сократиться, поскольку не каждый ученый сможет оплатить доступ к закрытой статье. При выборе журнала открытого доступа автору, возможно, придется самому оплачивать затраты на опубликование статьи или искать спонсора.

Отметим, что помимо двух альтернатив (открытый доступ - платный доступ) существуют также гибридные модели. Политика журнала может быть подвижной. Журнал с платным для читателя доступом открывает бесплатный доступ к некоторым публикациям, если авторы этих статей внесут определенную плату. Или платный для авторов журнал Открытого доступа может не взимать плату с некоторых категорий авторов. Финансовые издержки в этом случае берут на себя фонды поддержки научных исследований или сами издатели.

Если автор решил опубликовать свою статью в платном для читателей журнале, у него чаще всего сохраняется возможность предварительно разместить статью в виде 
препринта в Открытом репозитории ${ }^{1}$ на сайте своей организации, в каком-либо тематическом Открытом архиве препринтов или на своей персональной странице. Часто автор заинтересован именно в оперативной публикации. Издательский процесс традиционного журнала может занимать несколько месяцев. За это время автор может лишиться приоритета в своей области, а материал статьи может потерять актуальность. Многие журналы ограниченного доступа допускают возможность появления в интернете препринтов, например, журналы издательства Springer [5]. Но издательство выдвигает условие: если авторская версия статьи публикуется в виде препринта, то после принятия статьи редакция журнала предлагает автору указать в препринте, что статья была принята и опубликована в указанном журнале.

В том случае, когда статья была опубликована в виде препринта в Открытом репозитории, скорее всего, информация об этом препринте через некоторое время дойдет до массового читателя. В обеспечении широкого доступа к статье, размещенной на открытом сайте, большую роль играют поисковые сервисы, такие как Google, Яндекс. С помощью своих роботов поисковый сервис извлекает метаданные ${ }^{2}$ статей и размещает ее в своих индексах. Если в поисковых сервисах возникает запрос на поиск статьи, то с большой вероятностью нужная статья окажется в списке найденных ответов. Сложнее обстоит дело с индексирование статьи в Google Scholar. Далеко не каждый сайт может быть проиндексирован в этом сервисе. Для этого нужно, чтобы статья (или сайт) отвечали определенным требованиям к оформлению [6].

Может ли автор отказаться от повторного опубликования своего препринта в виде журнальной статьи? Вряд ли. Для получения статуса полноценного научного труда статья должна быть опубликована в рецензируемом журнале. Но тогда возникает проблема этического свойства — повторная публикация фактически одного и того же текста. Некоторые программы поиска совпадающих текстов типа «Антиплагиат» без труда выявляют подобного рода совпадения, и автору потом придется объясняться, что он на самом деле не нарушал этические нормы $[7,8]$. И вот теперь следует обратить внимание на новый тип научного журнала — оверлейный ${ }^{3}$ журнал, реализующий нетрадиционную схему организации взаимодействия автора и редакции журнала [9].

Оверлейный журнал придерживается трех принципов: открытый доступ, бесплатно публиковать, читать без ограничений. Реализовать провозглашенные принципы помогает уменьшение себестоимости выпуска оверлейного журнала за счет существенного снижения стоимости размещения статей в открытом доступе.

Схема взаимодействия автора и издателя оверлейного журнала состоит в следующем. Автор публикует свою статью в каком-либо открытом репозитории.

\footnotetext{
${ }^{1}$ Репозиторий - хранилище данных. В репозитории на сайте научного учреждения или вуза хранятся, обычно в открытом доступе, препринты, отчеты, статьи, монографии и пр.

${ }^{2}$ Метаданные - данные, относящиеся к дополнительной информации о содержимом или объекте. Метаданные статьи включают название, ФИО авторов, организации авторов, аннотацию статьи, ключевые слова и т.д. Метаданные передаются в библиографические базы для реализации на их основе поисковых запросов.

${ }^{3}$ Оверлейный журнал - тип научного журнала открытого доступа, который реализуется как надстройка «поверх» статей, уже размещенных в открытом доступе. Статьи рецензируются, окончательная версия принятой к публикации статьи вновь размещается на прежнем месте. Журнал размещает только метаданные статьи (название, авторы, аннотация и др.) вместе со ссылкой на полный текст. Источником статей для оверлейного журнала часто служат серверы препринтов.
} 
Статья проходит модерацию, организованную держателями репозитория. После этого автор направляет в оверлейный журнал соответствующей тематики размещенную в репозитории статью. Журнал проводит рецензирование статьи. В случае получения положительной рецензии и принятия статьи к публикации, статье присваивается DOI. Окончательная версия прошедшей рецензирование статьи повторно размещается в репозитории в виде новой версии вместе с ссылкой на журнал. Оверлейный журнал публикует только метаданные статьи и ссылку на окончательный текст статьи на сайте репозитория. Таким образом, оверлейный журнал представляет собой набор метаданных и ссылок на полные тексты статей, прошедших рецензирование.

Одним из примеров поддержки издания оверлейного журнала является платформа Episciences [10]. Интерфейс с издательской платформой полностью охватывает все стадии издательского процесса — от представления до опубликования статьи и дальнейшее сопровождение статьи. В настоящее время на платформе размещено уже полтора десятка журналов открытого доступа, придерживающихся оверлейной схемы.

Сфера деятельности серверов препринтов постоянно расширяется. Можно предположить, что в ближайшем будущем оверлейные журналы займут достойную нишу и найдут своих авторов и читателей в различных исследовательских сообществах.

\section{3 РЕЦЕНЗИРОВАНИЕ}

Научные журналы с высокими академическими стандартами весьма требовательно относятся к качеству публикуемых статей. Все статьи проходят обязательное рецензирование. Такие журналы открыто публикуют свою издательскую политику и этические нормы. Журналы, в частности, заботятся, чтобы у автора статьи и рецензента не было «конфликта интересов». Автор должен рассчитывать на объективное рассмотрение своей статьи без влияния групповых интересов или антагонизма конкурирующих научных школ.

Но все же рецензирование в журналах нередко дает сбои. Далеко не каждый рецензент может дать объективную оценку статье. Давайте вспомним, для сравнения, как проходит анализ диссертационных работ. Процедуры защиты предполагают наличие двух или трех оппонентов. Рассматривается также отзыв организации, назначенной диссертационным советом в качестве ведущей организации. Кроме того, при защите диссертации учитываются отзывы ученых, приславших свои оценки и замечания по диссертации. Решение по диссертации принимается коллегиально всеми членами совета. По понятным причинам такой уровень рассмотрения работы рецензенты журналов обеспечить не смогут.

Следует также упомянуть, что один из трудоемких этапов рецензирования часто связан с обнаружением в статье плагиата и «самоплагиата». В отношении плагиата вопросов не возникает: плагиат является не только очевидным этическим нарушением, но и нарушением законодательства об авторском праве. Чего нельзя сказать о «самоплагиате»: повторное использование автором своего ранее написанного текста не противоречит действующему законодательству. Напротив, практикуемая некоторыми изданиями борьба с таким повторным использованием текстов нередко нарушает права автора. Включение автором фрагментов текста из своих ранее опубликованных работ часто диктуется необходимостью представить контекст проведения исследования. 
Авторы могут использовать ранее опубликованные тексты с целью обеспечить самодостаточность текста статьи. Для читателя более удобно иметь перед глазами самодостаточный текст, пусть даже и содержащий фрагменты ранее изданной статьи автора, чем делать переход на другую статью, теряя контекст текущего повествования. Тем не менее, некоторые этические кодексы считают подобный «самоплагиат» некорректной издательской практикой. Редакторы журналов стараются избегать возможных конфликтов и могут отклонить статью, если встретят пересечения с ранее опубликованными статьями. Тем самым журнал не публикует статью, которая на самом деле является добросовестной научной работой [11].

Другой пример. Если редакция журнала берет с автора деньги за опубликование статьи, то часто коммерческие интересы журнала заслоняют объективность рецензирования. Известно также, что нередко журналы, добившись высоких рейтингов, начинают торговать своей популярностью. Такие «хищнические» журналы обещают авторам быстрое попадание в престижные западные базы и вынуждают авторов платить тысячи долларов за эту возможность. Об объективном рецензировании в таких случаях речь уже не идет.

Известны случаи, когда под видом научных журналов издательства запускают рекламные рыночные проекты. Такая история случилась с известной фирмой Elsevier [12]. В период с 2000 по 2005 год австралийское отделение Elsevier выпустило серию сборников статей, предназначенных для семейных врачей, которые фактически были рекламой продукции одной фармакологической компании. Когда вскрылась эта неприятная для Elsevier история, генеральный директор отдела наук о здоровье Michael Hansen опубликовал заявление. Он признался, что это была недопустимая практика, издательство сожалеет, что такой случай имел место [13].

Примеры можно продолжить. В 2012 г. была опубликована книга британского врача и учёного Бена Голдакра «Вся правда о лекарствах: мировой заговор фармкомпаний», посвященная описанию договорных схем между представителями фармацевтической промышленности и медиками. Медики часто выполняли роль рекламщиков, публикуя статьи о несуществующих достижениях. Приводились случаи, когда всплывали факты давления на исследователей со стороны фармацевтических компаний с целью выпустить на рынок непроверенные лекарственные препараты. В 2013 г. эта книга была издана в США, а в 2015 г. была переведена на русский язык [14].

Можно упомянуть еще один повод для сомнений во всеобъемлющей объективности рецензирования. Научные знания и технологии развиваются стремительно. Возникают новые направления, в том числе на стыке нескольких дисциплин. Нередко в научной среде возникает конфликт поколений: молодые исследователи часто используют современные методы, которыми не владеют специалисты старшего поколения. Если рецензент классического журнала не имеет опыта в новой области и не знаком с ее спецификой, он вряд ли сможет объективно оценить пионерскую статью. История науки знает множество примеров, когда новые революционные идеи долго не могли пробиться через стену непонимания традиционалистов.

Таким образом, классическое рецензирование в традиционном журнале имеет не менее серьезные риски, чем не слишком глубокая модерация статьи, применяемая, в частности, в arXiv.org. Не следует забывать о том, что существуют и другие не менее надежные способы убедиться в качестве статьи. Как правило, интересные и полезные для специалистов статьи имеют хорошие показатели посещаемости и высокие 
показатели альтернативных метрик. Тут можно говорить и о высоких показателях библиографической цитируемости, но с некоторыми оговорками.

\section{4 ЦИТИРОВАНИЕ С ПОМОЩЬЮ БИБЛИОГРАФИЧЕСКИХ ССЫЛОК}

Библиография в статье стала играть особую роль после появления библиографических баз, агрегирующих данные научных журналов, и после создания методов компьютерной обработки библиографических ссылок из текстов статей. Появилась возможность автоматически выявлять связи между статьями, между журналами на основе анализа списков цитируемой литературы. Бурное развитие получила библиометрия как совокупность методов оценки публикационной активности ученых, методов построения рейтингов журналов. Период увлечения библиометрией еще не закончился. Столпами библиометрии стали ведущие западные базы Web of Science и Scopus, многие крупные национальные электронные хранилища. Свой вклад в библиометрическое движение вносит крупнейшая российская Научная электронная библиотека eLibrary.

Некоторые страны, проводя оценку эффективности национальных исследований, опираются на показатели цитирования научных статей. В других странах, например в Великобритании, при оценке результативности научной деятельности используют в основном экспертную оценку. Проведенное недавно исследование UK Research Excellence Framework (REF) выявило заметные расхождения между метриками, основанными на цитировании, и результатами экспертных оценок. Следует отметить, что более ранние аналогичные исследования демонстрировали более высокую степень согласия метрик и экспертных оценок, что и стало поводом вводить метрические показатели. Теперь же появилась значительная неопределенность в целесообразности опоры на метрические показатели цитирования [15].

Если вы планируете, например, опубликовать статью в ведущем журнале Nature, то вам придется подготовить библиографический список из 30-40 позиций. Короткий библиографический список редакция может воспринять как отсутствие у автора необходимого кругозора в рассматриваемой области исследования. Но дело здесь не только и даже не столько в демонстрации погруженности в предметную область. На библиографических списках базируется целая индустрия оценки качества статей и престижности журналов. На базе подсчета числа цитирований статьи в других статьях вычисляется индекс Хирша автора. На базе подсчета цитирований статей журнала подсчитывается импакт-фактор журнала. И далее строятся рейтинги авторов и журналов на основе этих показателей. Но, когда некая технология накладывается на реальную издательскую практику, часто возникают противоестественные отношения между участниками процесса. Формируется особое поведение авторов и редакций журналов. Авторы могут договариваться о взаимном цитировании. Аналогичный сговор может возникнуть у группы журналов с целью поднять импакт-фактор друг другу. Тут же возникают посредники с предложениями повысить индекс Хирша за определенную плату: в интернете можно найти десятки предложений такого типа.

Стоит отметить, что показатели цитируемости на основе анализа библиографических списков не являются точными и всеобъемлющими. Существует проблема потерянных ссылок. Эта проблема возникает тогда, когда авторы отклоняются от предписанных 
форматов библиографических ссылок, делают существенные ошибки в написании фамилий и имен авторов, допускают неточности в названии статьи или других параметрах ссылки. Обычно в библиографических базах имеются инструменты, с помощью которых можно найти потерянные цитирования, отредактировать неточные библиографические ссылки. В работе [16] описан опыт исправления библиографических ссылок, указывающих на российские журналы, индексируемые в Web of Science. После коррекции ссылок показатели импакт-фактора группы российских журналов в Web of Science увеличились на 4-37\%. Можно привести еще один убедительный пример: после уточнения ссылок на статьи издания «Препринты ИПМ им. М.В. Келдыша» в eLibrary.ru в 2017 г. число цитирований издания выросло в три раза.

К недостаткам показателей, основанных на анализе библиографических ссылок, следует отнести их привязку к конкретной библиографической базе. Если на вашу статью ссылаются из статей и журналов, не относящихся по тематике к направлениям библиографической базы, то такие цитирования не будут учитываться. В итоге автор имеет сразу несколько существенно разнящихся показателей индекса Хирша от разных библиографических баз. Проблема объединения счетчиков цитирования одной и той же статьи из разных библиографических баз пока не имеет всеобъемлющего решения. Подходы к решению этой проблемы представлены в работе [17].

Кроме того, показатели индекса Хирша и импакт-фактора журналов весьма инерционны, они формируются длительное время и рассчитываются обычно не чаще одного раза в год. Для расчета двухлетнего показателя требуется наличие в базе выпусков журнала за 3 предыдущих года, а для пятилетнего показателя нужны выпуски журналов за 5 предыдущих лет.

Более динамично показатели цитируемости формируются на основе анализа библиографических списков статей в системе Google Scholar. Эта система использует данные самых разнообразных открытых онлайновых источников. Процесс сбора данных автоматизирован: разработаны программы, которые просматривают вебстраницы и извлекают информацию из описаний метаданных, а также непосредственно из текстов статей. B Google Scholar индекс Хирша автора обычно выше аналогичных показателей таких библиографических баз как Web of Science, Scopus или российской электронной библиотеки eLibrary.ru.

Еще один недостаток показателя цитируемости - игнорирование контекста и причины цитирования. В большинстве случаев цитирование говорит о высокой популярности статьи. Однако автор может сослаться на статью и по причине несогласия с отдельными положениями или с общими выводами статьи. Сославшись на статью с некорректным, по мнению автора, содержанием, автор далее в своей статье высказывает свое собственное альтернативное мнение. Но традиционная библиографическая ссылка не передает контекст цитирования, тем самым автор плохой статьи будет повышать свой показатель цитируемости и претендовать на статус авторитетного ученого.

Существует также проблема забытых авторов, которые первыми получили весомые результаты. Эта проблема может возникнуть, когда автор опубликовал свои пионерские результаты в скромном журнале без высоких рейтингов. Статью может процитировать и раскрыть суть опубликованных результатов другой автор, публикующийся в более престижном журнале. Далее читатели, заинтересовавшиеся опубликованным 
результатом, предпочтут процитировать публикацию в престижном журнале, поскольку они тем самым с помощью авторитета цитируемого журнала повышают авторитет своей собственной статьи. Такие цепочки цитирований приводят к потере информации об авторе, первым получившим интересный научный результат. В продолжение этой темы можно привести пример препринтов. Известно, что после публикации препринта автор обычно публикует по материалам препринта статью в журнале. Далее мы нередко видим, что число цитирований препринта намного меньше числа цитирований журнальной статьи. И это несмотря на то, что именно препринт является первоисточником полученного научного результата.

\section{5 АЛЬТМЕТРИКИ И КРАУДСОРСИНГ}

Развивающиеся интернет-технологии заметно изменили подходы к оценке значимости статей, влияния изложенных в статьях идей на развитие науки. Появились инструменты, позволяющие подсчитывать количество обращений к научной статье и число скачиваний статьи, показывать географию обращений. Большинство держателей научных интернет-ресурсов заводят на своих сайтах счетчики вебометрической информации. Инструменты веб-аналитики продолжают развиваться. Предпринимаются попытки выделить набор количественных показателей, дающих понятную и однозначную оценку уровня мотивации посетителя к знакомству с материалами ресурса [18].

Не следует думать, что высокое качество статьи заведомо обеспечит ей успех в вебсреде. Автор обязан позаботиться о том, чтобы статью легко было заметить.

Один из самых распространенных способов найти статью - сделать запрос в универсальном поисковом сервисе (например, в Google). Если поиск был успешным, то это свидетельствует о неплохой видимости статьи в интернете. Однако, если автор статьи активно пользуется социальными сетями и участвует в форумах, посвященных обсуждению научных проблем, его видимость в интернете дополнительно возрастает. Появилось отдельное направление [19], связанное с оценкой популярности статьи в таких пока еще нетрадиционных для ученых системах как социальные сети, форумы, специализированные платформы для научных дискуссий. Это направление получило название - альтметрики ${ }^{4}$. Манифест альтметрик был опубликован в 2010 г. [20].

Результаты научных исследований являются многомерными. Они могут включить в себя достижения в конкретном научном направлении, в междисциплинарной методологии, в развитии технологий проведения исследований. Наконец, научные результаты могут иметь социальный эффект, привносящий новые идеи в широкие социальные слои - от исследователей до политических деятелей. Оценка такого научного результата должна быть также многомерной, здесь едва ли можно с успехом применить какую-либо одну метрику или одну модель оценки [21].

Большой объем материала, связанного с развитием научных идей и осмыслением полученных результатов, не попадает в традиционные журнальные статьи. Такие

\footnotetext{
${ }^{4}$ Альтметрики в научных публикациях — это альтернатива и дополнение к традиционным показателям библиометрии. Альтметрики отражают интерес интернет-аудитории к онлайновой статье. Альтметрики включают количество закладок, сделанных читателями в Mendeley, CiteULike и других системах, количество просмотров и скачиваний статьи, упоминаний в социальных сетях и т.д.
} 
материалы остаются в записях открытых дискуссий, на персональных страницах ученых, на страницах институтских сайтов, в учебных материалах для студентов, в комментариях к статьям, в публикациях в средствах массовой информации [22]. С помощью существующих сервисов, таких как Mendeley, CiteULike или Zotero ученый может организовать свою личную библиотеку материалов, не имеющих формат научной статьи, и тем самым сделать эти материалы доступными для пользователей интернета [20].

В некоторых случаях ученый может написать небольшую заметку, которую в дальнейшем могли бы цитировать другие ученые. Однако подобную «нанопубликацию» традиционный журнал, скорее всего, не сможет опубликовать. Как следствие, читатели не смогут отыскать заметку с помощью поисковых средств, ориентированных на поиск журнальных статей. Здесь требуются другие поисковые запросы. Альметрия должна создавать механизмы учета такого рода «нанопубликаций».

Ученые широко обмениваются наборами данных, программными кодами, методиками проведения экспериментов, алгоритмами и т.д. («сырой наукой», raw science). Авторы, получившие такие данные, не набирают традиционных оценок авторитетности - их индекс Хирша не зависит от результатов, связанных с получением и размещением на сайтах или в архивах наборов данных. Требуются другие индикаторы, которые бы учитывали такой вклад ученого. Это направление также входит в зону интереса альтметрии.

Одной из характеристик статьи является рецензия. До недавнего времени материалы рецензий оставались на полках издательств. В настоящее время нередко реализуется идея размещения рецензий вместе со статьей в открытом доступе, что также укладывается в философию альтметрии. Кроме того, современная рецензия перестает быть одномоментным текстом, сопровождающим статью. Структура рецензионных материалов усложняется. Процесс рецензирования развивается в диалоге рецензента с автором, и содержание этого диалога представляет интерес для читателей статьи. Также возникают версии статьи с очередными изменениями, сделанными по итогам дискуссии. Уже после публикации статьи автор может получить новую рецензию от заинтересованных экспертов, или провести рецензирование в другом оверлейном журнале. Рецензирование, вообще говоря, не ограничено во времени. Каждое рецензирование дает повод для автора продолжать развивать свой опубликованный материал. Тем самым статья превращается в «живую публикацию» [23].

Технологии интернета и идеология Открытой науки позволяют реализовать рецензирование в стиле краудсорсинга ${ }^{5}$, когда в оценке качества интернет-ресурса участвует представительное сообщество экспертов, а не только назначенные редакцией рецензенты. Такой подход к рецензированию реализован, например, в проекте F1000research [24], где оценку статье и ее дополнительным материалам может дать любой из нескольких тысяч экспертов данного проекта.

\footnotetext{
${ }^{5}$ Краудсорсинг (от анг. crowd - толпа) — привлечение широкого круга лиц для выполнения работы на добровольных началах. В издательской деятельности краудсорсинг стал обозначать новую схему рецензирования и обсуждения научной статьи, когда в оценке качества статьи участвует представительное сообщество экспертов, а не только назначенный редакцией рецензент. Обычно, например в проекте F1000Research, по результатам обсуждения с экспертами статья в любое время может быть обновлена и дополнена.
} 
F1000research - издательская платформа Открытой науки для быстрого опубликования научных статей в области физических и биологических наук, инженерии, медицины, социальных и гуманитарных наук. Как организован процесс рецензирования на этой платформе? К публикации принимаются оригинальные статьи вне зависимости от предполагаемого уровня интереса или новизны. Все статьи публикуются в открытом доступе. Авторам предлагается дополнительно приложить к тексту статьи подробные описания методов, постеры, слайды. Также у автора есть возможность дать ссылку на исходные данные, лежащие в основе исследования, чтобы обеспечить воспроизводимость результатов.

Представленная в F1000Research статья сначала проходит быструю первоначальную проверку на соответствие общей редакционной практике и размещается на сайте со статусом «Ожидание экспертной оценки». Далее проводится открытое рецензирование, при этом авторы и рецензенты сотрудничают, чтобы сделать статью как можно более полной. Имена рецензентов и статус, который они присваивают статье после рецензирования, публикуются вместе со статьей. В дальнейшем любой другой эксперт издательства F1000Research также вправе по собственной инициативе прорецензировать статью, дополнительно уточняя ее статус. Как только статья получает два статуса «Одобрено», или два статуса «Одобрено с оговорками» и один статус «Одобрено», она будет проиндексирована в различных библиографических базах данных (в PubMed, PubMed Central, MEDLINE и др.). Если статья проиндексирована, все версии вместе с отчетами о рецензировании отправляются на хранение.

Имеются ли у экспертов стимулы брать на себя работу по рецензированию статей? Да, в проекте F1000Research такой механизм создан. Имя эксперта и его рецензии открыты для всего сообщества, тем самым активно и добросовестно работающий эксперт повышает свой рейтинг. Кроме того, для экспертов, участвующих в рецензировании статей, предусмотрена заметная скидка при оплате его личного взноса за будущие публикации [25]. Путем стимулирования активности экспертов и авторов проект F1000Research консолидирует научное сообщество и дает возможность каждому ученому участвовать в формировании коллективного научного продукта.

Статьи в F1000Research могут быть обновлены и дополнены в любое время после публикации, и каждая версия может быть независимо цитируемой со своим собственным DOI. Редакция предлагает следующий формат ссылки на статью [26]:

Author name(s). Article title [version number; details of peer review status]. F1000Research Year, Volume: Publication number (article doi)

Все компоненты приведенной библиографической ссылки понятны для читателя. Дополнительных разъяснений потребует атрибут «Статус». Статус характеризует количество проверок, которые «одобрены», «одобрены с оговорками» или «не одобрены». Кроме того, независимо от статьи, рецензия сама становится объектом цитирования. Рецензия публикуется под лицензией СС BY 4.0, каждой рецензии присваивается DOI. Платформа предлагает следующий формат ссылки на рецензию [26]:

Reviewer name(s). Peer review report for: Article title [version number; details of peer review status]. F1000Research Year, Volume: Publication number (review doi) 


\section{5 ЗАКЛЮЧЕНИЕ}

По нашему мнению, оценка научной статьи должна быть многоплановой. Классическое рецензирование имеет риски не менее серьезные, чем неглубокое модерирование, за которым следует краудсорсинг, действующий в течение всего времени существования статьи. Краудсорсинг в научном издании можно определить простыми словами: сообщество ученых является мощным ресурсом, и подключение этого ресурса к рецензированию научных статей дает возможность получить более качественный научный продукт. На сайте статьи, помимо рецензии, читателю интересно было бы увидеть альтметрические показатели, полученные на основе информации из социальных сетей, тематических блогов и форумов для профессионального общения.

Оценка научной значимости статьи уже несколько десятилетий ориентируется только лишь на библиометрические показатели, основанные на анализе библиографических ссылок на статью. По нашему мнению, получение показателей на основе анализа библиографических ссылок в цитирующих статьях оказывается слишком долгим по времени, чувствительным к ошибкам записи ссылок и нерепрезентативным, поскольку обычно ограничено одной конкретной библиографической базой.

Перспективным направлением в научной издательской практике является оверлейный журнал, который рецензирует статьи из открытых архивов препринтов. После публикации статьи автор может получить новую рецензию от заинтересованных экспертов, или провести рецензирование в другом оверлейном журнале. Пострецензирование, вообще говоря, не ограничено во времени. Рецензии и отклики коллег вдохновляют автора продолжать развивать свою статью. Тем самым статья превращается в «живую публикацию».

Навязанная научному сообществу борьба за высокие показатели библиографического цитирования и за наращивание числа публикаций в высокорейтинговых журналах заслоняет существенно более значимые задачи: развитие инфраструктуры Открытого доступа, создание инструментов коммуникации для участников издательского процесса, обогащение средств презентации научных материалов на открытых издательских платформах.

\section{REFERENCES}

[1] M. M. Gorbunov-Posadov, T. A. Polilova, "Tools to Support Scientific Online Publishing", Programming and Computer Software, 45 (3), 116-120 (2019). https://link.springer.com/article/10.1134\%2FS0361768819030046

[2] S. Beliaeva, "Tsena otkrytosti: Vo chto oboidetsia perekhod k Open Access?", Poisk. (2019). https://www.poisknews.ru/skript/czena-otkrytosti-vo-chto-obojdetsya-perehod-k-open-access/

[3] J.R. Adler, T.M. Chan, J.B. Blain, B. Thoma, Atkinson, "OpenAccess: Free online, open-access crowdsource-reviewed publishing is the future; traditional peer-reviewed journals are on the way out", Canadian Journal of Emergency Medicine, 21 (1), 11- 14 (2019). https://doi.org/10.1017/cem.2018.481

[4] Fair Open Access Alliance. https://www.fairopenaccess.org/ (Accessed July 22, 2020)

[5] Springer, Self-archiving policy. https://www.springer.com/gp/open-access/publicationpolicies/self-archiving-policy (Accessed July 22, 2020) 
[6] Google Scholar, Inclusion Guidelines for Webmasters. https://scholar.google.com/intl/enUS/scholar/inclusion.html\#overview (Accessed July 22, 2020)

[7] T.A. Polilova. "Ethical norms and legal framework of scientific publication". Mathematica Montisnigri, XLV, 129-136 (2019) http://www.montis.pmf.ac.me/vol45/11.pdf doi: 10.20948/mathmontis-2019-45-11

[8] T.A. Polilova, "Nauchnaia publikatsiia v Rossii: intellektualnye prava", Preprinty IPM im. M.V. Keldysha. 56, 1-24 (2019). http://keldysh.ru/papers/2019/prep2019 56.pdf doi:10.20948/prepr-2019-56

[9] E. Herman, J. Akeroyd, G. Bequet, D. Nicholas, A. Watkinson. "The changed - and changing - landscape of serials publishing: Review of the literature on emerging models", Learned Publishing. (2020). https://doi.org/10.1002/leap.1288 https://onlinelibrary.wiley.com/doi/full/10.1002/leap.1288

[10] Episciences.org, Overlay Journal Platform. www.episciences.org/?lang=en (Accessed July $22,2020)$

[11] T. Polilova, A. Ermakov, "Dissernet and self-plagiarism", CEUR Workshop Proceedings, 2543, 285-294 (2020). https://www.scopus.com/record/display.uri?eid=2-s2.085078459740\&origin $=$ resultslist $\&$ sort $=$ plf- $\mathrm{f} \& \mathrm{src}=\mathrm{s} \& \mathrm{st} 1=$ Dissernet + and + selfplagiarism\&st $2=\&$ sid $=\mathrm{d} 8727 \mathrm{e} 9 \mathrm{f} 55 \mathrm{ec} 2 \mathrm{~b} 7 \mathrm{fc} 177 \mathrm{de} 73 \mathrm{ce} 64 \mathrm{e} 6 \mathrm{~d} 1 \& \mathrm{sot}=\mathrm{b} \& \mathrm{sdt}=\mathrm{b} \& \mathrm{sl}=44 \& \mathrm{~s}=\mathrm{TITL}$ E-ABS-KEY\%28Dissernet+and+self-plagiarism\%29\&relpos $=0 \&$ citeCnt $=0 \&$ searchTerm $=$ (Accessed July 22, 2020)

[12] Wikipedia, Elsevier. https://ru.wikipedia.org/wiki/Elsevier (Accessed July 22, 2020)

[13] Tom Reller. Statement From Michael Hansen, CEO Of Elsevier's Health Sciences Division, Regarding Australia Based Sponsored Journal Practices Between 2000 And 2005. https://www.elsevier.com/about/press-releases/clinical-solutions/statement-from-michaelhansen,-ceo-of-elseviers-health-sciences-division,-regarding-australia-based-sponsoredjournal-practices-between-2000-and-2005 (Accessed July 22, 2020)

[14] "Vsia pravda o lekarstvakh, Google i bestsellerah, Galina Iuzefovich — pro knigi, kotorye vse obieiasniaiut". https://meduza.io/feature/2015/07/04/vsya-pravda-o-lekarstvah-google-ibestsellerah (Accessed July 22, 2020)

[15] V.A. Traag, L. Waltman, "Systematic analysis of agreement between metrics and peer review in the UK REF", Palgrave Communications, 5, Article number: 29 (2019). https://doi.org/10.1057/s41599-019-0233-x

[16] D.E. Chebukov, "Poisk poteriannykh tsitirovanii v Web of Science. Ispravlenie oshibok v spiskakh literatury Web of Science", Nauchnyi servis v seti Internet, 461-467 (2017). http://keldysh.ru/abrau/2017/77.pdf doi:10.20948/abrau-2017-77

[17] YongGao QiangWu LinnaZhu, "Merging the citations received by arXiv-deposited e-prints and their corresponding published journal articles: Problems and perspectives", Information Processing \& Management, 57 (5), (2020). https://doi.org/10.1016/j.ipm.2020.102267

[18] Iu.G. Reviakin, "Web-analitika dlia nauchnykh publikatsii", Preprinty IPM im. M.V. Keldysha, 50, 1-42 (2020). http://keldysh.ru/papers/2020/prep2020_50.pdf doi:10.20948/prepr-2020-50

[19] M.N. Saushkin, D.E. Chebukov, "Altmetriki na saite nauchnogo zhurnala", Nauchnyi servis v seti Internet, 593-599 (2019). http://keldysh.ru/abrau/2019/theses/40.pdf doi:10.20948/abrau-2019-40

[20] J. Priem, D. Taraborelli, P. Groth, C. Neylon, “Altmetrics: A manifesto", (2010). http://altmetrics.org/manifesto (Accessed July 22, 2020)

[21] M. V. Vakhrushev, "Altmetriki, vebometriki i informetriki kak vzaimodopolniaiushchie napravleniia v sovremennoi bibliometrii", Nauchnye i tekhnicheskie biblioteki, 8, 67-76 (2019). https://ntb.gpntb.ru/jour/article/viewFile/470/453

[22] A. Grossmann, "Publishing in transition - do we still need scientific journals?", ScienceOpen 
Research, (2015). https://www.scienceopen.com/document_file/e1dd3665-6406-4a32-befce00d84a72cd1/ScienceOpen/3077_XE696973259861784096.pdf doi: 10.14293/S21991006.1.SOR-SOCSCI.ACKE0Y.v1

[23] M.M. Gorbunov-Posadov, "Zhivaia publikatsiia", (Moscow: KIAM). https://keldysh.ru/gorbunov/live.htm (Accessed July 22, 2020)

[24] F1000Research. Open for Science. https://f1000research.com/ (Accessed July 22, 2020)

[25] F1000Research. Open for Science: Referee Incentives. http://f1000research.com/refereeincentives (Accessed July 22, 2020)

[26] F1000Research. Open for Science: How it Works. https://f1000research.com/about (Accessed July 22, 2020)

Received June 10, 2020 